LETTERS

\title{
Recurrent limp in a young boy
}

\section{F Falcini, T Giani, A Lippi, M Resti, G Simonini}

A child aged 2 years 8 months was referred to our rheumatology unit for evaluation of recurrent acute pain and limited motion of the left hip.

In March 2003 he had been seen at the emergency department of our hospital for a painful, flexed, and abducted left hip. On that occasion, the erythrocyte sedimentation rate (ESR) was $35 \mathrm{~mm} / \mathrm{lst} \mathrm{h}$, white blood cells (WBC) $8.3 \times 10^{9} / \mathrm{l}$, and $C$ reactive protein (CRP) $32.7 \mathrm{mg} / \mathrm{l}$ (normal value $<5 \mathrm{mg} / \mathrm{l}$ ). Ultrasound of the joint showed mild effusion with normal synovial thickness on the left hip, and a transient hip synovitis (THS) was diagnosed. The pain and limp responded to a 3 day course of anti-inflammatory drug treatment.

One month later, the boy returned again with a limp and pain in the left hip. Because the symptoms resolved over few days with analgesic administration, laboratory tests or ultrasound were not performed.

The child was well up to November 2003, when the hip pain and limping returned without any other musculoskeletal or constitutional symptoms. Abnormal laboratory results were as follows: ESR $34 \mathrm{~mm} / \mathrm{lst} \mathrm{h}$, CRP $6.5 \mathrm{mg} / \mathrm{l}$, WBC $5.9 \times 10^{9} / \mathrm{l}$ (neutrophils $45.3 \%$, lymphocytes $44.3 \%$ ), haemoglobin $109 \mathrm{~g} / \mathrm{l}$, platelet count $127 \times 10^{9} / \mathrm{l}$, serum lactate dehydrogenase $(\mathrm{LDH}) \quad 1216 \mathrm{U} / \mathrm{l}$ (normal value <560). Bacterial and viral infections were all excluded. Ultrasound of both hips excluded joint effusion, while an $x$ ray examination showed an area of reduced bone density in the left femoral neck. Magnetic resonance imaging with gadolinium showed foci of increased uptake in bone marrow of the left ileum and in periarticular left ischiopubic and ileopubic areas close to the hip. Although a peripheral blood smear did not disclose any abnormality, a bone marrow aspirate analysis showed a myeloblastic leukaemia FAB M2 (fig 1). The boy was then referred to the oncology unit.

\section{DISCUSSION}

Limping is a common and challenging problem in children and adolescents. A complete history and thorough physical examination with pertinent laboratory tests and imaging studies are necessary to establish an early diagnosis. ${ }^{1}$

In the absence of constitutional symptoms, THS is the most common cause of sudden onset of limp and flexed and abducted hip in a young boy. The measures of inflammation are normal or slightly raised, joint ultrasound shows effusion on the hip, and $x$ ray findings may be normal or show widening of the joint space. The condition may recur and responds to a short treatment with analgesic. ${ }^{2}$

In our patient, the clinical symptoms suggested a diagnosis of THS at initial presentation. After the third episode of limping, an $x$ ray examination was recommended to rule out osteonecrosis of the femoral head, a possible complication of THS in about $3 \%$ of patients. The increased level of LDH prompted us to investigate further by means of a bone marrow aspirate. In children with musculoskeletal complaints, increased values of $\mathrm{LDH}$ may help to distinguish patients with rheumatic diseases from those with malignancies at the beginning of illness when symptoms and other laboratory data are not yet helpful. ${ }^{34}$

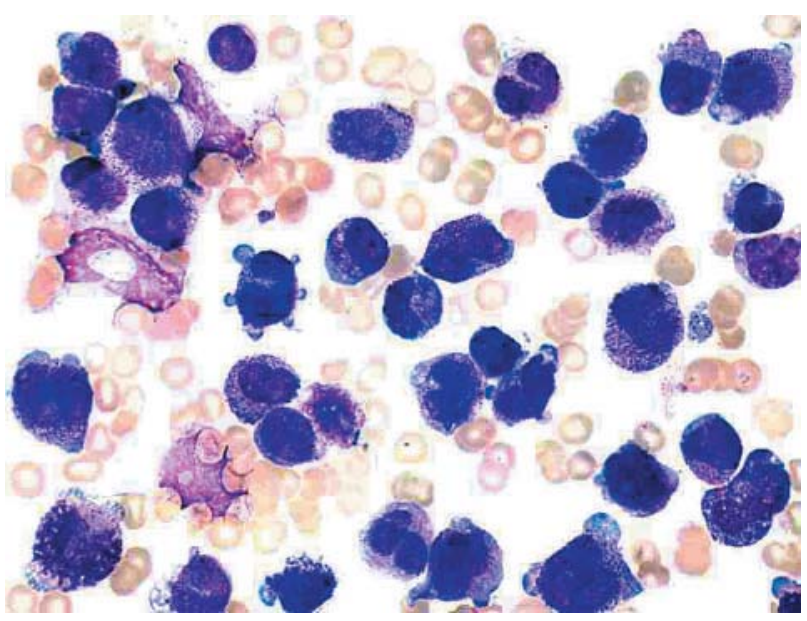

Figure 1 Bone marrow aspirate showing substitution of normal haematopoiesis with myeloblasts: myeloblastic leukaemia FAB M2.

Our case suggests that malignancy should be considered with a differential diagnosis of recurrent hip pain in children. Recurrent joint symptoms associated with recurrent febrile episodes might also indicate the autoinflammatory diseases spectrum, even though high LDH levels are quite unusual and unexpected in these conditions.

When hip pain recurs, evaluation of LDH could be added to the required blood tests; an increased LDH value should indicate to physicians that they can rule out malignancy.

Acute myeloblastic leukaemia accounts for about $20 \%$ of all cases of acute leukaemia in children, resulting in osteoarticular changes in up to $23 \%$ of cases. The early diagnosis is a good prognostic feature of this childhood malignancy and misleading and delayed diagnosis can easily occur when classic features of the disease are lacking. ${ }^{5}$

\section{Authors' affiliations}

F Falcini, T Giani, G Simonini, Rheumatology Unit Department of Paediatrics, University of Florence, Italy

A Lippi, M Resti, Oncology Unit, A. Meyer Children's Hospital, Italy

Correspondence to: Dr F Falcini, Department of Paediatrics,

Rheumatology Unit, Via Pico della Mirandola 24, 50132 Firenze, Italy; falcini@unifi.it

Accepted 17 July 2004

\section{REFERENCES}

1 Gunner KB, Scott AC. Evaluation of a child with a limp. J Pediatr Health Care 2001;15:38-40

2 Do $\Pi$. Transient synovitis as a cause of painful limps in children. Curr Opin Pediatr 2000;12:48-51.

3 Cabral DA, Tucker LB. Malignancies in children who initially present with rheumatic complaints. J Pediatr 1999;134:53-7.

4 Wallendal M, Stork L, Hollister JR. The discriminating value of serum lactate dehydrogenase levels in children with malignant neoplasms presenting as joint pain. Arch Pediatr Adolesc Med 1996;150:70-3.

5 Athale UH, Kaste SC, Razzouk BI, Rubnitz JE, Ribeiro RC. Skeletal manifestations of pediatric acute megakaryoblastic leukaemia. J Pediatr Hematol Oncol 2002;24:561-5. 


\title{
Finger joint swellings in a teenager: juvenile rheumatoid arthritis or a psychiatric disorder?
}

\author{
B Ostendorf, C Iking-Konert, M Cohnen, M Schneider
}

Ann Rheum Dis 2005;64:501-502. doi: 10.1136/ard.2004.023234

I n January 2002 a 14 year old Turkish teenager presented to his doctor with a history of 3 months' swelling of the proximal interphalangeal (PIP) joints of both hands. As arthritis was suspected, he was referred to an orthopaedic surgeon. Blood tests, including $\mathrm{C}$ reactive protein, rheumatoid factor, were normal, conventional radiography of both hands showed only soft tissue swellings of the PIP joints. Under the diagnosis of "juvenile rheumatoid arthritis", treatment with a non-steroidal anti-inflammatory drug was started. As the "polyarthritis" persisted, he was introduced to another orthopaedist. Three phase bone scintigraphy (technetium-99m) disclosed intensive "hot spots" at the PIP joints (phase 2) and at the epiphysial growth plate of the upper and lower extremities (static bone phase).

In July 2003, after three other medical consultations, he was admitted to our department. He denied any other symptoms or complaints besides finger swellings (fig 1), predominantly of PIP 2 and 3 of both hands, without signs of hypermobility and functional restriction. Routine blood tests, erythrocyte sedimentation rate, $\mathrm{C}$ reactive protein, rheumatoid factor, cyclic citrullinated peptide, antinuclear antibodies, and HLA-B27 were normal. Follow up radiographs of hands and feet (posteroanterior and oblique) were normal (Larsen score 1) and showed non-consolidated epiphyses. Tendon or ligament injuries, signs of synovial effusion, or active synovitis were not detected by ultrasound $(12.5 \mathrm{MHz}$ high frequency transducer). To detect early signs of arthritis, magnetic resonance imaging (MRI; $1.5 \mathrm{~T}$ ) of the right hand was performed, showing periarticular swelling of the joint capsules of the PIP joints (fig 2); no osseous oedema, erosions, cystic lesions, or synovitis after intravenous gadolinium diethylenetriaminepentaacetic acid (Gd-DTPA; Magnevist, Schering AG, Berlin; not shown) was seen.

We discussed the discrepancy between the clinical findings and diagnostic results, and he finally reported a nervous habit that he had had for at least 2 years: cracking his fingers 10 times a minute. This psychiatric disorder had remained undetected during various medical consultations. In view of

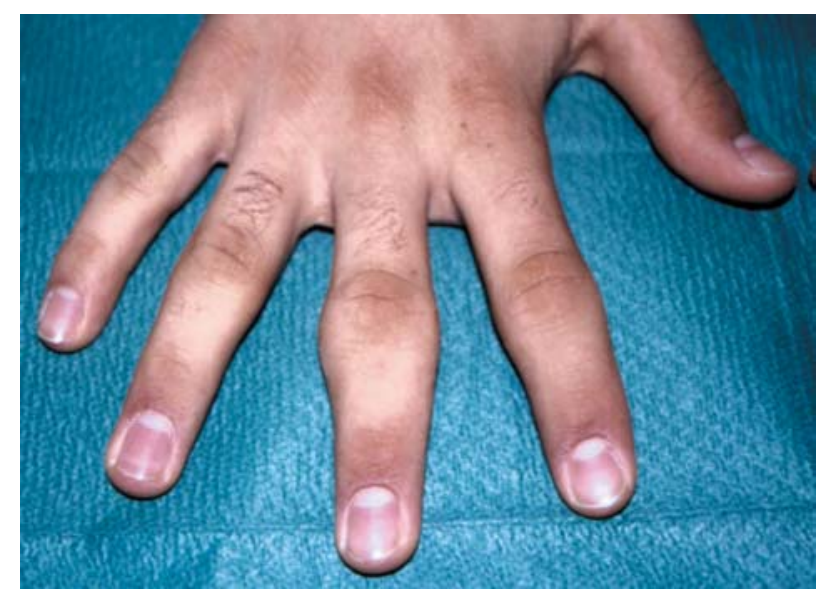

Figure 1 Patient's right hand with swelling of the PIP joints. these new aspects, the MRI sections were re-evaluated, but tendon, ligament, or finger pulley injuries could be ruled out. The patient was discharged with the diagnosis of an "overuse syndrome secondary to a nervous tick" and was referred to a psychiatric consultant for behaviour therapy, which he stopped after a few sessions without having benefited.

\section{DISCUSSION}

In our patient only severe swellings of the PIP joints of both hands correspond to the revised criteria of juvenile idiopathic arthritis (JIA). ${ }^{1}$ Because of the discrepancies in the former diagnostic findings, we performed MRI, which disclosed periarticular swellings of the PIP joints but neither synovitis nor damage to cartilage or bone. Based on this, we reevaluated the patient's history radically. Finally, the young man admitted cracking his fingers continuously for the past 2 years, a fact that led to the diagnosis of an "overuse syndrome secondary to a nervous tick" $^{\prime 2}$ as a psychiatric disorder and not to JIA. Neither specific hints in his history for a factitious disease/Munchhausen syndrome ${ }^{3}$ nor criteria for joint hypermobility syndromes, ${ }^{4}$ heritable disorders of connective tissue or storage diseases, Thiemann's disease ${ }^{5}$ or osteochondrodysplasia could be found. The patient's

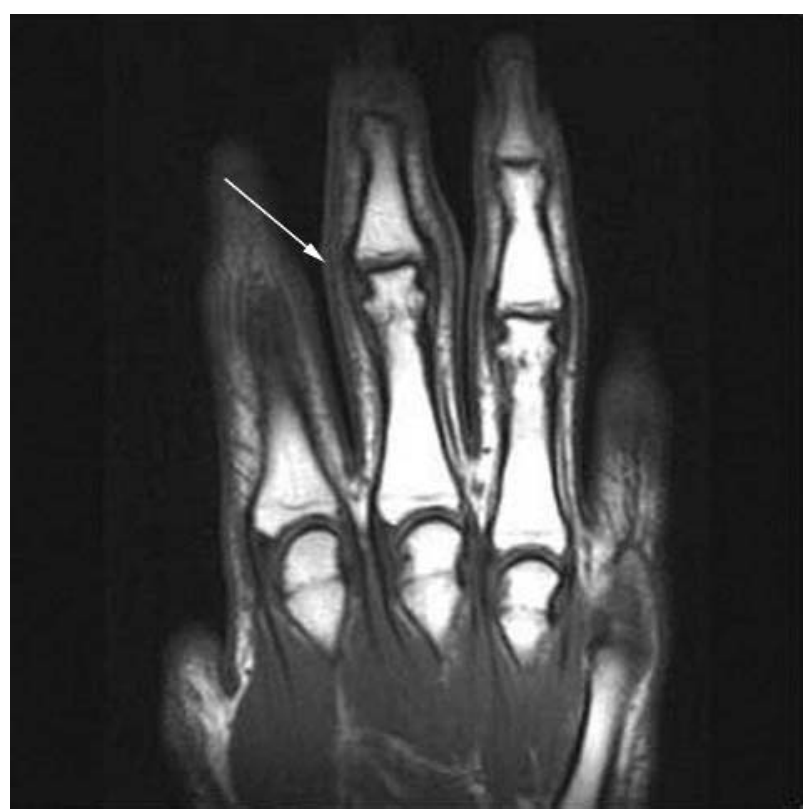

Figure 2 Coronal $\mathrm{T}_{1}$ weighted MRI image of the right hand (TR/TE: $500 / 15 \mathrm{~ms}$, Thk: $3 \mathrm{~mm}$, FoV: $10-15 \mathrm{~cm}$, matrix size: $512 \times 192$ pixels, TA: 6 minutes 20 seconds) showing periarticular swelling of soft tissue as well as of the joint capsule at PIP joints 2 and 3 (arrow) without signs of the start of osteodestruction or marrow oedema. Metacarpophalangeal joints (1-5) and carpal bones/wrist were also of normal structure (not shown). Sequences were obtained as follows: coronal $\mathrm{T}_{2}$ weighted turbo-spin echo (SE), coronal fat suppressed short $\tau$ inversion recovery sequence, coronal and sagittal $\mathrm{T}_{1}$ weighted $\mathrm{SE}$ before and immediately after application of Gd-DTPA, and axial fat suppressed $\mathrm{T}_{1}$ weighted SE sequences with Gd-DTPA. 
swellings were most probably due to chronic overuse and extensive stress of the PIP joints, a phenomenon known to some extent in, for example, extreme rock climbers. ${ }^{2}$

Ultrasound and MRI have emerged as alternatives or supplements to conventional radiography in imaging small joint abnormalities in patients with arthritis or trauma. ${ }^{6-10}$ MRI visualises structural bone damage (oedema and erosions) as well as signs of disease activity (synovitis) as indicated by Gd-DTPA. However, MRI is not usually necessary to reach a diagnosis of JIA, but when there are atypical features and diagnostic doubt, it is a useful additional investigative tool. In our case, MRI helped to exclude both JIA and minor traumatic lesions, once we had become aware of the patient's overuse syndrome.

\section{Authors' affiliations}

B Ostendorf, C Iking-Konert, M Schneider, Department of

Rheumatology, Heinrich-Heine-University Düsseldorf, 40225 Düsseldorf Germany

M Cohnen, Institute of Diagnostic Radiology, Heinrich-Heine-University Düsseldorf, 40225 Düsseldorf, Germany

Editor: Anthony D Woolf

Correspondence to: Dr B Ostendorf, ostendorf@med.uni-duesseldorf.de

\section{REFERENCES}

1 Petty RE, Southwood TR, Baum J, Bhettay E, Glass DN, Manners P, et al. Revision of the proposed classification criteria for juvenile idiopathic arthritis: Durban, 1997. J Rheumatol 1998;25:1991-4

2 Klauser A, Frauscher F, Bodner G, Halpern EJ, Schocke MF, Springer P, et al Finger pulley injuries in extreme rock climbers: depiction with dynamic US. Radiology 2002;222:755-61.

3 Turner J, Reid S. Munchausen's syndrome. Lancet 2002;359:346-9.

4 Hakim A, Grahame R. Joint hypermobility. Best Pract Res Clin Rheumatol 2003;17:989-1004.

5 Gewanter H, Baum J. Thiemann's disease. J Rheumatol 1985;12:150-3.

6 Grassi W, Filippucci E, Farina A, Salaffi F, Cervini C. Ultrasonography in the evaluation of bone erosions. Ann Rheum Dis 2001;60:98-103.

7 Backhaus M, Kamradt T, Sandrock D, Loreck D, Fritz J, Wolf KJ, et al. Arthritis of the finger joints: a comprehensive approach comparing conventional radiography, scintigraphy, ultrasound, and contrastenhanced magnetic resonance imaging. Arthritis Rheum 1999:42:1232-45

8 Savnik A, Malmskov H, Thomsen HS, Graff LB, Nielsen H, DanneskioldSamsoe B, et al. MRI of the wrist and finger joints in inflammatory joint diseases at 1-year interval: MRI features to predict bone erosions. Eur Radiol 2002; 12:1203-10.

9 Ostendorf B, Peters R, Dann P, Becker A, Scherer A, Wedekind F, et al. Magnetic resonance imaging and miniarthroscopy of metacarpophalangeal joints: sensitive detection of morphologic changes in rheumatoid arthritis. Arthritis Rheum 2001:44:2492-502.

10 Hauger O, Chung CB, Lektrakul N, Botte MJ, Trudell D, Boutin RD, et al. Pulley system in the fingers: normal anatomy and simulated lesions in cadavers at MR imaging, CT, and US with and without contrast material distention of the tendon sheath. Radiology 2000;217:201-12.

\title{
Worse patient VAS occurs at weeks 7 and 8 after infliximab infusions
}

\author{
N Shenker, R Haigh, A Clarke
}

Ann Rheum Dis 2005;64:502-503. doi: 10.1136/ard.2004.021725

$\mathrm{T}$ he new tumour necrosis factor $\alpha(\mathrm{TNF} \alpha)$ blockers are revolutionising the treatment of patients with resistant rheumatoid arthritis. Generally good response rates are seen and the treatments are well tolerated. These agents, however, are costly and questions about their long term side effects remain. In the UK, the administration of infliximab and etanercept has been reviewed by NICE, and guidelines were published in March, 2002. ${ }^{1}$ They recommend that "non-responders" discontinue treatment after 3 months. Non-responders are defined by a Disease Activity Score using a 28 joint count (DAS28) that remains greater than 3.2 or has not reduced by at least 1.2 from the score before treatment.

Anecdotal evidence suggests that patients become increasingly symptomatic towards the end of the 8 weeks between infusions. Therefore, despite an obvious sustained clinical improvement immediately after their infusion, their DAS28 may still be high at the eighth week. We have previously described a patient with active rheumatoid arthritis whose disease did not respond to the 8 weekly regimen but who has continued to have good disease control with a 6 weekly regimen. ${ }^{2}$ Does patient wellbeing deteriorate over the 8 weeks for patients already established on infliximab? We asked all our patients on such a regimen to rate their disease on a self administered patient global wellbeing visual analogue scale (VAS) for each of the 8 weeks between infusions.

Eighteen patients were identified and all successfully completed the VAS sheets. The Wilcoxon signed rank test using week 1 as comparator was used to detect significance. Figure 1 presents the results obtained.
This survey uses a simple but pragmatic outcome measure (patient global wellbeing VAS) to indicate that patients who receive infliximab do not have a uniform sustained response. There was a significant trend for patients to notice a general decrease in their wellbeing towards the end of the 8 week interval. It should be noted that a global patient VAS is a subjective measure that can be influenced by the patient's expectations. A patient's global VAS, however, is used as a

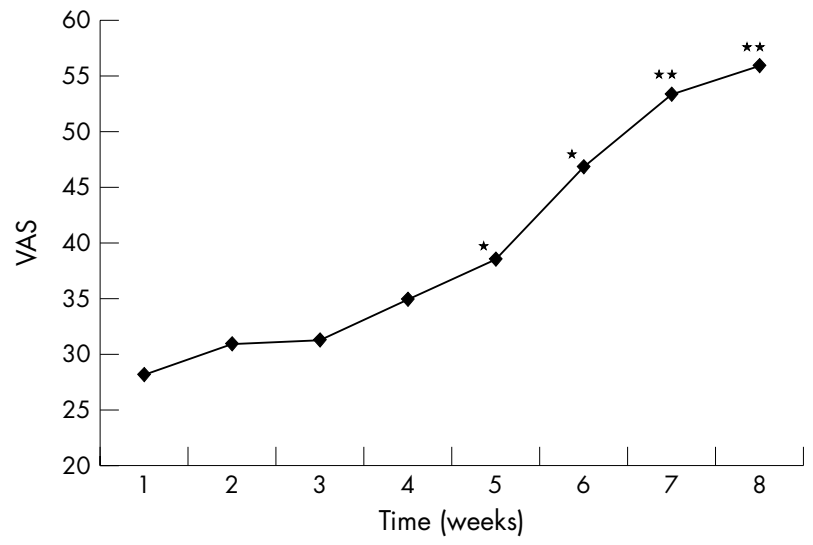

Figure 1 Global VAS for each week between infliximab infusions $(\mathrm{n}=18) .{ }^{*} \mathrm{p}<0.05$ (Wilcoxon signed rank test using week 1 as comparator); ${ }^{* *} p<0.01$ 
component of the more objective DAS28. Clearly, the DAS28 will vary depending upon its temporal relationship with respect to the infusion.

Disease response to infliximab has been related to serum levels. ${ }^{3}{ }^{4}$ Individual variations in pharmacodynamics mean that in a proportion of patients infliximab clears more rapidly. St Clair et al found that $26 \%$ of all patients had undetectable trough levels of serum infliximab at week 54 on a $3 \mathrm{mg} / \mathrm{kg} 8$ weekly regimen. ${ }^{3}$ Maini et al noted that patients not treated with methotrexate cleared serum infliximab more rapidly. The role of new antibody production in this observation is unclear at present but may be relevant. ${ }^{4}$ Should patients have their trough serum infliximab levels measured before being classified as a "non-responder" in the current national guidelines?

If patients with undetectable trough serum infliximab levels are identified, how should they be treated? Should they have higher doses, such as $5 \mathrm{mg} / \mathrm{kg}$ and an 8 weekly regimen, or more frequent infusions? St Clair et al compared $3 \mathrm{mg} / \mathrm{kg}$ 6 weekly regimens with a dose increase of $100 \mathrm{mg}$ using pharmacodynamic modelling and concluded that a 6 weekly regimen would yield a higher trough serum level.

In conclusion, TNF $\alpha$ antagonists are an effective but costly treatment for rheumatoid arthritis. We have performed a pragmatic survey demonstrating a decrease in patient wellbeing over the 8 weeks between infliximab infusions. Nonresponders should not be defined by looking at the week 8 DAS28 without taking the clinical response over time into account. This finding has implications for the frequency of infliximab administration and the timing of DAS28 assessments.

\section{Authors' affiliations}

N Shenker, A Clarke, Department of Rheumatology, Royal National Hospital for Rheumatic Diseases, Bath, BA1 1RL, UK

R Haigh, Department of Rheumatology, Royal Devon and Exeter Hospital, Exeter, UK

Correspondence to: Dr N Shenker, mpxns@bath.ac.uk

Accepted 7 April 2004

\section{REFERENCES}

1 Guidance of the use of etanercept and infliximab in the treatment of rheumatoid arthritis. Technology Appraisal No 36, NICE, March, 2002.

2 Shenker N, Haigh R, Michell L, Calin A. Case report of infliximab leading to disease control in a man with active rheumatoid arthritis who had previously failed etanercept [abstract]. Rheumatology (Oxford) 2002;41:S91.

3 St Clair EW, Wagner CL, Fasanmade AA, Wang B, Schaible T, Kavanaugh A, et al. The relationship of serum infliximab concentrations to clinical improvement in rheumatoid arthritis: results from ATRACT, a multicenter, randomized, double-blind, placebo-controlled trial. Arthritis Rheum 2002;46:1451-9.

4 Maini RN, Breedveld FC, Kalden JR, Smolen JS, Davis D, Macfarlane JD, et al. Therapeutic efficacy of multiple intravenous infusions of anti-tumor necrosis factor alpha monoclonal antibody combined with low-dose weekly methotrexate in rheumatoid arthritis. Arthritis Rheum 1998;41:1552-63.

\section{Glucocorticoid receptor polymorphisms in Korean patients with rheumatoid arthritis}

\section{E B Lee, J Y Kim, Y J Lee, Y W Song}

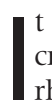
t has been suggested that dysregulation of the neuroendocrine system is an important pathogenetic mechanism of rheumatoid arthritis (RA). The dramatic response of patients with RA to glucocorticoids, the aggravation of RA after resection of bilateral adrenal glands, the inappropriately normal plasma cortisol levels in patients with RA, the blunted plasma cortisol responses after surgical stress, and the essential role of glucocorticoids in the development of streptococcal cell wall induced arthritis in Lewis rats provide evidence that dysregulation of the hypothalamic-pituitaryadrenal (HPA) axis or relative glucocorticoid deficiency might play a part in the development of RA. ${ }^{12}$ The involvement of glucocorticoids in the development of thymocytes further supports the role of glucocorticoid in autoimmune diseases like RA. ${ }^{3}$

The human glucocorticoid receptor (hGR) is a transcriptional factor activated by glucocorticoids, and regulates the expressions of various inflammatory cytokine genes by interacting with DNA bound NF- $\mathrm{KB}$ or activator protein 1 . The hGR gene is located on chromosome 5 (locus 5q31) and consists of nine exons and eight introns. ${ }^{4}$ Of the several single nucleotide polymorphisms identified in the hGR gene, the BclI restriction fragment length polymorphism (RFLP) was found to be located in intron 2, $647 \mathrm{bp}$ from the exon 2/intron 2 junction. ${ }^{5}$

BclI RFLP was found to be associated with tissuespecific corticosteroid sensitivity. ${ }^{6}{ }^{7}$ Furthermore, BclI GG homozygotes showed increased cortisol response to a standardised lunch ${ }^{8}$ and depressed response to severe psychosocial stress. ${ }^{9}$ These findings suggest that the BclI polymorphism of hGR plays a part in the dysregulation of the HPA axis. The role of the BclI polymorphism in corticosteroid sensitivity and dysregulation of the HPA axis suggests that it may play a part in the pathogenesis of RA. Therefore, we investigated the hGR $+647 \mathrm{G} / \mathrm{C}$ genetic polymorphism in Korean patients with RA and in healthy blood donors matched for age and sex, in an attempt to understand the role of the HPA axis related hGR polymorphism in the development of RA.

A total of 149 Korean patients with RA were enrolled at the rheumatology clinic of Seoul National University Hospital between March 1998 and February 2000. All patients fulfilled the 1987 American Rheumatism Association revised criteria for the classification of RA. ${ }^{10}$ The patients comprised 132 women and 17 men, with mean (SD) age 50.8 (12.1) years and a mean disease duration of 7.9 years (range $0.17-50.2$ ). Rheumatoid factor was present in $112(75 \%)$ and HLA-DR4 in $86(58 \%)$, radiographic erosions were found in $100(67 \%)$, and extra-articular complications in 25 (17\%) patients. One hundred and forty nine Korean healthy blood donors matched for age and sex were enrolled as controls.

Genomic DNA was extracted from peripheral blood using a QIAamp blood kit (Qiagen, Valencia, USA), and HLA-DR4 was genotyped by polymerase chain reaction (PCR)-single strand conformation polymorphism. The hGR +647 G/C polymorphism was genotyped by PCR-RFLP, using 
Table 1 Bcll restriction fragment length polymorphism of human glucocorticoid receptor gene in Korean patients with RA versus healthy controls

\begin{tabular}{|c|c|c|c|c|c|c|}
\hline & $\begin{array}{l}\text { RA } \\
(n=149)\end{array}$ & $\begin{array}{l}\text { Controls } \\
(n=149)\end{array}$ & $\chi^{2}$ & $p$ Value & OR & $95 \% \mathrm{Cl}$ \\
\hline \multicolumn{7}{|c|}{ Genotype } \\
\hline GG & $77(51.7)$ & $86(57.7)$ & 2.55 & 0.28 & & \\
\hline GC & $63(42.3)$ & $59(39.6)$ & & & & \\
\hline $\mathrm{CC}$ & $9(6.0)$ & $4(2.7)$ & & & & \\
\hline \multicolumn{7}{|c|}{ Allele } \\
\hline G & $217(72.8)$ & $231(77.5)$ & 1.76 & 0.18 & 0.78 & 0.53 to 1.13 \\
\hline C & $81(27.2)$ & $67(22.5)$ & & & & \\
\hline
\end{tabular}

5' -AAA TTG AAG CTT AAC AAT TTT GGC-3', and 5'-GCA GTG AAC AGT GTA CCA GAC C-3' as primers, and BClI endonuclease (New England Bioblabs, Beverly, USA). ${ }^{5}$

Genotype or allele frequencies of hGR $+647 \mathrm{G} / \mathrm{C}$ did not differ between patients with RA and controls (table 1) (allele frequencies of hGR G/C were 0.73/0.27 in patients and 0.78/ 0.22 in the controls $(\mathrm{p}=0.18, \mathrm{OR}=0.78,95 \%$ CI 0.53 to 1.13). Subgroup analysis showed no genotype or allele frequency differences between the patients with rheumatoid factor, joint erosion, or extra-articular complications and the healthy controls. When patients were stratified according to HLA-DR4 status, these results were unchanged. In conclusion, hGR +647 G/C polymorphisms probably do not play a part in the pathogenesis of RA in Korean patients.

\section{ACKNOWLEDGEMENTS}

This study was supported by a grant from the Ministry of Science and Technology of Korea through the National Research Laboratory Programme.

\section{Authors' affiliations}

E B Lee, J Y Kim, Y J Lee, Y W Song, Department of Internal Medicine, Clinical Research Institute, Medical Research Centre, Seoul National University College of Medicine, Seoul, Korea

Correspondence to: Professor Y W Song, Department of Internal Medicine, Seoul National University College of Medicine, 28 Yungondong, Chongno-gu, Seoul 110-744, Korea; ysong@snu.ac.kr

Accepted 20 June 2004

\section{REFERENCES}

1 Wilder RL, Elenkov IJ. The neuroendocrine axis in rheumatoid arthritis, In: Firestein GS, Panayi GS, Wollheim FA, eds. Rheumatoid arthritis. Frontiers in pathogenesis and treatment. 1st ed. Oxford: Oxford University Press, 2000:243-53.

2 Sternberg EM, Hill JM, Chrousos GP, Kamilaris T, Listwak SJ, Gold PW, et al. Inflammatory mediator-induced hypothalamic-pituitary axis activation is defective in streptococcal cell wall arthritis-susceptible Lewis rats. Proc Natl Acad Sci USA 1989;86:2374-8.

3 King LB, Vacchio MS, Dixon K, Hunziker R, Margulies DH, Ashwell JD. A targeted glucocorticoid receptor antisense transgene increases thymocyte apoptosis and alters thymocyte development. Immunity 1995;3:647-56.

4 Derijk RH, Schaaf M, de Kloet ER. Glucocorticoid receptor variants: clinical implications. J Steroid Biochem Mol Biol 2002;81:103-22.

5 Fleury I, Beaulieu P, Primeau M, Labuda D, Sinnett D, Krajinovic M. Characterization of the Bcll polymorphism in the glucocorticoid receptor gene. Clin Chem 2003;49:1528-31.

6 Panarelli M, Holloway CD, Fraser R, Connell JM, Ingram MC, Anderson NH, et al. Glucocorticoid receptor polymorphism, skin vasoconstriction, and other metabolic intermediate phenotypes in normal human subjects. J Clin Endocrinol Metab 1998;83:1846-52.

7 van Rossum EF, Koper JW, van den Beld AW, Uitterlinden AG, Arp P, Ester W, et al. Identification of the Bcll polymorphism in the glucocorticoid receptor gene: association with sensitivity to glucocorticoids in vivo and body mass index. Clin Endocrinol (Oxf) 2003;59:585-92.

8 Rosmond R, Chagnon YC, Holm G, Chagnon M, Perusse L, Lindell K, et al. A glucocorticoid receptor gene marker is associated with abdominal obesity, leptin, and dysregulation of the hypothalamic-pituitary-adrenal axis. Obes Res 2000;8:211-18.

9 Wust S, van Rosssum EF, Federenko IS, Koper JW, Kumsta R, Hellhammer DH. Common polymorphisms in the glucocorticoid receptor gene are associated with adrenocortical responses to psychosocial stress. J Clin Endocriol Metab 2004;89:565-73.

10 Arnett FC, Edworthy SM, Bloch DA, McShane DJ, Fries JF, Cooper NS, et al. The American Rheumatism Association 1987 revised criteria for the classification of rheumatoid arthritis. Arthritis Rheum 1988;31:315-24.

\section{Tenascin-X: a candidate gene for benign joint hypermobility syndrome and hypermobility type Ehlers-Danlos syndrome?}

\section{C Zweers, M Kucharekova, J Schalkwijk}

J oint hypermobility is a common finding, differing strongly between sexes and among races. ${ }^{1}$ Joint hypermobility is not a disease in itself, but it can be part of heritable connective tissue disorders, such as Marfan syndrome, Ehlers-Danlos syndrome (EDS), and benign joint hypermobility syndrome (BJHS). ${ }^{2}$ Although Marfan syndrome and most types of EDS are clinically relatively easy to distinguish by their cardinal features, it is often less easy to differentiate between the hypermobility type of EDS (HT-EDS, formerly type III) and BJHS. Recently, Grahame et al proposed a validated set of diagnostic criteria for $\mathrm{BJHS}^{3}$ : the revised Brighton 1998 criteria. Its major criteria are a Beighton score of 4/9 or greater and arthralgia, but the diagnosis can also be based on the presence of minor criteria, including abnormal skin and joint (sub)luxations. HT-EDS can be identified by the Villefranche criteria; the major criteria of this classification include a Beighton score of $5 / 9$ or greater and skin involvement. ${ }^{4}$ Clearly, there is considerable overlap in the clinical features of BJHS and HT-EDS.

Little is known about the genetic basis of HT-EDS or BJHS. Recently, we have shown that haploinsufficiency for the extracellular matrix protein tenascin- $X$ is associated with HTEDS. ${ }^{5}$ Tenascin- $X$ is abundantly expressed in almost all connective tissues, and a $140 \mathrm{kDa}$ fragment is present in 
serum. The level of serum tenascin-X probably reflects the rate of tenascin- $X$ synthesis in the connective tissues, because subjects who are heterozygous for a tenascin-X null allele express about half of the normal level in their serum. ${ }^{6}$ Clinically, tenascin-X haploinsufficient subjects show generalised joint hypermobility, arthralgia, and about $40 \%$ of them have abnormal skin.

In this study, we investigated whether haploinsufficiency for tenascin-X also occurs in subjects who are diagnosed with BJHS. In collaboration with the Dutch BJHS patient organisation, we collected serum samples from 54 patients (53 female) diagnosed with BJHS by a medical specialist, most of whom were rheumatologists. We measured tenascin-X serum levels in these patients, and found that the mean (SD) level in the BJHS cohort group did not differ from that in the control group (97.6 (25.8)\% $\vee 100(14.1) \%$, respectively). Of these patients, $14(26 \%)$ had a tenascin- $X$ serum level below the 5 th centile of the controls (crude odds ratio $6.4,95 \%$ confidence interval 2.5 to 16.3 ). Furthermore, four of these patients (7\%, all female) had serum tenascin-X levels more than 2.5 standard deviations of control (65\%) below the mean for normal subjects. Only $0.6 \%$ of subjects would be expected to have such low tenascin- $X$ serum values based on the normal distribution, which is significantly less than the prevalence found in this BJHS group $(\mathrm{p}<0.05$, Fisher's exact test). Interestingly, the percentage of reduced tenascin-X serum levels in BJHS is similar to the percentage we described in HT-EDS. None of the previously identified truncating tenascin-X mutations were present in any of the patients. It is likely that these patients may have other mutations of tenascin-X or they may represent the extreme in normal variation of tenascin-X expression. Only two patients were available for clinical examination. Both patients had hypermobile joints, often associated with joint subluxations, and chronic musculoskeletal pain.
We have shown that reduced tenascin-X serum levels are present in $5-10 \%$ of the patients diagnosed with BJHS or HTEDS. ${ }^{5}$ These findings and the considerable overlap of the clinical symptoms suggest that no meaningful distinction can be made between these conditions. Both BJHS and HT-EDS are likely to be genetically heterogeneous and, clearly, the search for candidate genes has only just begun.

\section{Authors' affiliations}

M C Zweers, J Schalkwijk, Department of Dermatology, University Medical Centre Nijmegen, The Netherlands

M Kucharekova, Department of Dermatology, University Hospital Maastricht, The Netherlands

Correspondence to: Ms M C Zweers, Department of Dermatology, University Medical Centre Nijmegen, PO Box 9101, 6500 HB Nijmegen, The Netherlands; m.zweers@derma.umcn.nl

Accepted 16 July 2004

\section{REFERENCES}

1 Russek LN. Hypermobility syndrome. Phys Ther 1999;79:591-9.

2 Grahame R. Joint hypermobility and genetic collagen disorders: are they related? Arch Dis Child 1999;80:188-91.

3 Grahame R, Bird HA, Child A. The revised (Brighton 1998) criteria for the diagnosis of benign joint hypermobility syndrome (BJHS). J Rheumatol 2000;27:1777-9.

4 Beighton P, De Paepe A, Steinmann B, Tsipouras P, Wenstrup RJ. EhlersDanlos syndromes: revised nosology, Villefranche, 1997. Ehlers- Danlos National Foundation (USA) and Ehlers-Danlos Support Group (UK). Am J Med Genet 1998;77:31-7.

5 Zweers MC, Bristow J, Steijlen PM, Dean WB, Hamel BC, Otero M, et al. Haploinsufficiency of TNXB is associated with hypermobility type of EhlersDanlos syndrome. Am J Hum Genet 2003;73:214-17.

6 Schalkwijk J, Zweers MC, Steijlen PM, Dean WB, Taylor G, Van Vlijmen IM, et al. A recessive form of the Ehlers-Danlos syndrome caused by tenascin- $X$ deficiency. N Engl J Med 2001;345:1167-75.

\section{Multiple venous thrombosis in SAPHO syndrome}

\section{T Kawabata, Y Morita, A Nakatsuka, H Kagawa, M Kawashima, T Sei, M Yamamura, H Makino}

A 42 year old Japanese woman presented to our clinic complaining of severe pain in her neck, both shoulders, and lumbar spine. She had had pustulosis palmaris and plantaris from age 16 and recurrent painful swelling of the clavicles, the sternoclavicular joints, and the sternum from age 25. She reported multiple visits to the doctor for similar symptoms, and she was treated with non-steroidal anti-inflammatory drugs.

On initial examination at our clinic, her lumbar and cervical spine mobility was limited considerably. She had an oedematous face and subcutaneous collateral circulation on chest and abdomen. Laboratory testing showed a white cell count of $13.5 \times 10^{9} / 1$ and a $C$ reactive protein of $142 \mathrm{mg} / \mathrm{l}$ (normal <5). Antinuclear antibodies, antineutrophil cytoplasmic antibodies, anticardiolipin antibodies, lupus anticoagulants, and rheumatoid factors were all negative. Prothrombin time and activated partial thromboplastin time were normal. Locus B HLA typing was positive for B48 and $\mathrm{B} 52$. She reported that her $\mathrm{C}$ reactive protein level was always over $100 \mathrm{mg} / \mathrm{l}$.

Plain radiographs disclosed marked hyperostosis in the medial aspect of both clavicles. There was narrowing and ankylosis in the apophysial joints of the cervical spine, and complete ankylosis in both sacroiliac joints. Contrast enhanced computed tomographic scans demonstrated a soft tissue mass in the upper mediastinum (fig lA). Both subclavian veins were severely stenotic, and the superior vena cava (SVC) was almost completely occluded (fig 1B). Thrombosis was seen within the left internal jugular vein, and the right internal jugular vein could not be observed (fig 1C). Injection of contrast medium showed a network of collateral veins in the neck, chest, and abdominal wall. A diagnosis of SAPHO syndrome complicated by multiple venous thrombosis and SVC syndrome was made. Prednisolone was given at $10 \mathrm{mg} / \mathrm{day}$, and the pain in her shoulders, neck, and lumbar spine improved. The treatment also included warfarin for anticoagulation.

\section{DISCUSSION}

Venous thrombosis complicating SAPHO syndrome is uncommon. In a series of 120 patients with this syndrome, Hayem et al found that only one $(0.8 \%)$ patient had thrombosis of the subclavian vein. ${ }^{1}$ We found eight well documented cases of patients with SAPHO syndrome who developed venous thrombosis. ${ }^{2-8}$ Six of the patients had subclavian vein thrombosis, ${ }^{2-6}$ and only one case had SVC 

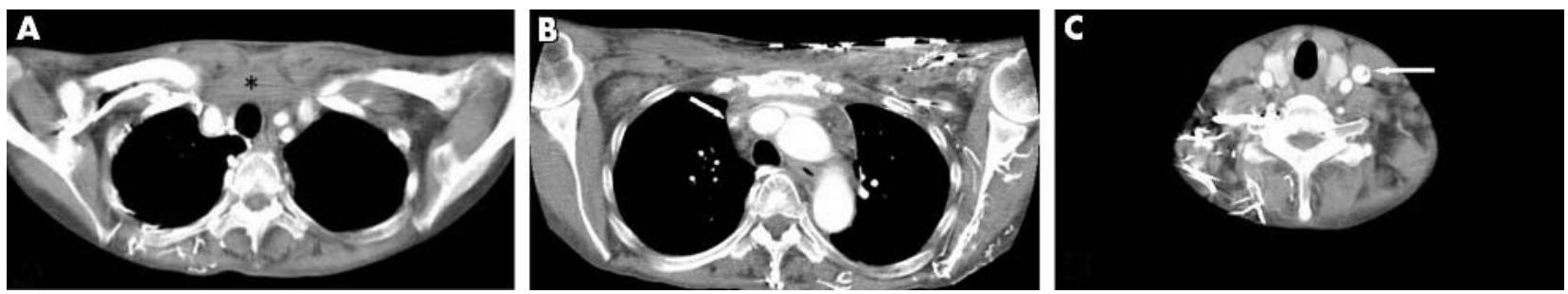

Figure 1 Contrast enhanced computed tomographic scans (A) demonstrating a soft tissue mass in the upper mediastinum (*); (B) showing almost complete occlusion of the SVC (arrow); and (C) thrombosis within the left internal jugular vein (arrow). In (C) The right internal jugular vein cannot be seen.

obstruction. ${ }^{7}$ In one of the eight patients, thrombosis of the iliac vein was found in a patient with lumbar vertebral osteitis and a large tissue mass surrounding the vein. ${ }^{8}$ The pathological mechanisms of venous thrombosis are still not clearly understood, but it is suggested that it is caused by vein compression by hyperostosis, or sheathing of the veins by an inflammatory and fibrotic tissue mass.

We have observed a new case of SVC obstruction in SAPHO syndrome, which is of particular interest, as multiple thrombi were observed, not only in the SVC and both subclavian veins but also in the internal jugular vein, which is not directly adjacent to the affected bones and the mediastinal mass. In our case the congestive venous flow may reflect the thrombosis in the internal jugular vein. Van Holsbeeck et al reported a case of a patient with SAPHO syndrome with bilateral subclavian vein obstruction who had a high level of lupus anticoagulant. ${ }^{6}$ Although our patient does not have any antiphospholipid antibodies, such factors may be associated with venous thrombosis in this syndrome.

SAPHO syndrome has some features of the spondyloarthropathies. Whether this syndrome is a unique subset of the spondyloarthropathies or is a distinct clinical entity is not well established. Nevertheless, the concept of SAPHO syndrome is useful in defining a subgroup of patients with unique clinical features. Venous thrombosis may lead to serious complications in patients with this syndrome. Our patient further emphasises the importance of recognising this complication in SAPHO syndrome.

\section{Authors' affiliations}

T Kawabata, A Nakatsuka, H Kagawa, M Kawashima, M Yamamura, H Makino, Department of Medicine and Clinical Science, Okayama University Graduate School of Medicine and Dentistry, Japan
Y Morita, Division of Nephrology and Rheumatology, Department of Internal Medicine, Kawasaki Medical School, Japan

T Sei, Department of Radiology, Okayama University Graduate School of Medicine and Dentistry, Japan

Correspondence to: $\operatorname{Dr} Y$ Morita, Division of Nephrology and Rheumatology, Department of Internal Medicine, Kawasaki Medical School, 577 Matsushima, Kurashiki 701-0192, Japan;

morita@med.kawasaki-m.ac.jp

Accepted 10 September 2004

\section{REFERENCES}

1 Hayem G, Bouchaud-Chabot A, Benali K, Roux S, Palazzo E, SilbermannHoffman O, et al. SAPHO syndrome: a long term follow-up study of 120 cases. Semin Arthritis Rheum 1999;29:159-71.

2 Köhler H, Uehlinger E, Kutzner J, West TB. Sternocostoclavicular hyperostosis: painful swelling of the sternum, clavicles, and upper ribs. Report of two new cases. Ann Intern Med 1977;87:192-7.

3 Jirik FR, Stein HB, Chalmers A. Clavicular hyperostosis with enthesopathy hypergammaglobulinemia, and thoracic outlet syndrome. Ann Intern Med 1982; $97: 48-50$

4 Haenel LC, Bradway WR, Costantini PJ. Thrombophlebitis complicating sternocostoclavicular hyperostosis. Postgrad Med 1980;68:1 13-5, 117-8.

5 Lazzarin P, Punzi L, Cesaro G, Sfriso P, De Sandre P, Padovani G, et al. Thrombosis of the subclavian vein in SAPHO syndrome. A case-report. Rev Rhum Engl Ed 1999;66:173-6.

6 Van Holsbeeck M, Martel W, Dequeker J, Favril A, Gielen J, Verschakelen J et al. Soft tissue involvement, mediastinal pseudotumor, and venous thrombosis in pustulotic arthro-osteitis. A study of eight new cases. Skeletal Radiol 1989; 18:1-8.

7 Cunningham T, Farrell J, Veale D, Fitzgerald $O$. Anterior mediastinal fibrosis with superior vena caval obstruction complicating the synovitis-acnepustulosis-hyperostosis-osteomyelitis syndrome. Br J Rheumatol 1993:32:408-10.

8 Legoupil N, Révelon G, Allain J, Voisin M-C, Rahmouni A, Chevalier X et al. lliac vein thrombosis complicating SAPHO syndrome: MRI and histologic features of soft tissue lesions. Joint Bone Spine $2001 ; 68: 79-83$

\title{
A potential pitfall in the use of the Disease Activity Score (DAS28) as the main response criterion in treatment guidelines for patients with rheumatoid arthritis
}

\author{
P V Gardiner, A L Bell, A J Taggart, G Wright, F Kee, A Smyth, R McKane, J Lee, M E Rooney, \\ E Whitehead
}

$\mathrm{T}$ he Disease Activity Score ${ }^{1}$ is widely used to quantify disease activity and gauge response to treatment. A rather complex calculation conceals the relative contribution of each measure to the composite score. The 28 joint version (DAS28) is used in the British Society for Rheumatology guidelines to determine response to anti-tumour necrosis factor $\alpha$ (anti-TNF $\alpha$ ) treatment. ${ }^{2}$ A reduction in DAS28 of $\geqslant 1.2$ is considered significant improvement, as is a reduction in DAS28 score to $<3.2$. These figures are important, as under current guidelines clinicians are advised to discontinue anti-TNF treatment if either of these criteria is not achieved at 3 months. 


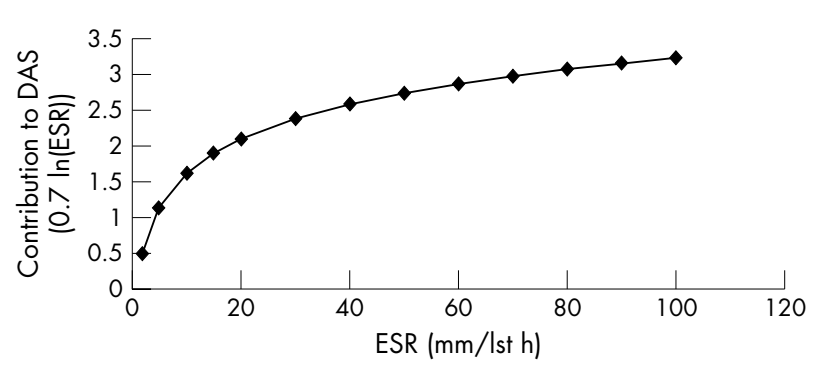

Figure 1 Contribution of ESR values to the DAS28 score.

In the course of reviewing decisions on whether or not to continue anti-TNF therapy, we identified several patients in whom the change in DAS28 score did not correlate with clinical findings. It was also noted that the clinicians relied heavily on the change in DAS28 score to determine if the treatment should be continued. In some cases, a relatively insignificant change in erythrocyte sedimentation rate (ESR) seemed to be responsible for a disproportionately great change in the DAS28 score.

To give an example, a 53 year old patient was treated with infliximab. At baseline his patient global assessment was 24, he had 10 swollen and five tender joints, and his ESR was $13 \mathrm{~mm} / \mathrm{lst} \mathrm{h}$, resulting in a DAS28 score of 5.25. At the 3 month review the patient global assessment was 25; there were eight swollen and two tender joints, and the ESR was $4 \mathrm{~mm} / \mathrm{h}$. The second DAS28 score was 3.8 , an impressive improvement of 1.45. Thus, even though there had been little or no discernible improvement, the DAS28 response exceeded the cut off point of 1.2 stipulated in the BSR guidelines. In this case, the guidelines advise continuation of treatment.

Figure 1 shows the contribution of the ESR to the DAS28 score. As a result of the log transformation of ESR values used to calculate the DAS28 score, changes in ESR below $20 \mathrm{~mm} / \mathrm{lst} \mathrm{h}$ have an inordinately large effect on the change in DAS28 score. Patients with a low initial ESR are thus more likely to show greater improvements in the DAS28 score than those with a high initial ESR. The contribution of an ESR change of 17 to $2 \mathrm{~mm} / \mathrm{h}$ to the change in DAS28 score is 1.5 , whereas a change in ESR from 90 to $60 \mathrm{~mm} / \mathrm{lst} \mathrm{h}$ would have contributed just 0.27 .

The DAS28 score continues to be a useful tool in clinical practice, particularly when auditing response to treatment in groups of patients. We would, however, caution against the use of the DAS28 score as the main response criterion in an individual patient, where the score seems to conflict with the assessments of the patient and clinician. In these cases misinterpretation may be avoided by careful evaluation of the individual components of the DAS28 score. It may be necessary to modify the guidelines to take into account situations where the change in DAS28 score is not representative of the clinical situation.

\section{Authors' affiliations \\ P V Gardiner, Altnagelvin Hospital, Londonderry, N Ireland A L Bell, A J Taggart, G Wright, M E Rooney, Musgrave Park Hospital, Belfast, $\mathrm{N}$ Ireland \\ F Kee, Northern Health and Social Services Board, Antrim, N Ireland A Smyth, R McKane, Ulster Hospital, Dundonald, N Ireland \\ J Lee, Craigavon Hospital, Craigavon, $\mathrm{N}$ Ireland \\ E Whitehead, Antrim Hospital, Antrim, N Ireland}

Correspondence to: Dr P V Gardiner, Altnagelvin Hospital, Glenshane Road, Londonderry BT47 1SB, N Ireland UK; pgardiner@alt.n-i.nhs.uk

Accepted 17 July 2004

\section{REFERENCE}

1 Prevoo ML, van't Hof MA, Kuper HH, van Leeuwen MA, van de Putte LB, van Riel PL. Modified disease activity scores that include twenty-eight-joint counts. Development and validation in a prospective longitudinal study of patients with rheumatoid arthritis. Arthritis Rheum 1995;38:44-8.

2 BSR. Guidelines for prescribing TNF- $\alpha$ blockers in adults with rheumatoid arthritis. Report of a working party of the British Society for Rheumatology. London: BSR, 2001.

\section{No improvement in a pilot study of tai chi exercise in rheumatoid arthritis}

\section{T Uhlig, C Larsson, A-G Hiorth, S Ødegård, T K Kvien}

$T^{2}$ ai chi, originally a Chinese martial arts, practises physical and mental integration with large, slow, and gracious movements. Tai chi has been shown to improve balance and prevent falls, ${ }^{1}$ increase flexibility, ${ }^{2}$ improve physical function, ${ }^{3}$ and has recently been applied in osteoarthritis. ${ }^{56}$ Little is known about possible beneficial effects of tai chi in rheumatoid arthritis (RA). We therefore performed an 8 week pilot study to explore the efficacy of a tai chi instruction programme on disease related measures in patients with RA.

\section{PATIENTS AND METHODS}

Fifteen women with RA aged $40-70$ years (mean (SD) age 57.0 (8.6) years, mean (SD) disease duration 12.3 (5.7) years) with at least moderate disability (modified Health Assessment Questionnaire (MHAQ) $\geqslant 1.5$ ) 1 year before the study were randomly selected from the Oslo RA register and included.

Before, after 4 weeks of intervention, and within 1 week after completion of the 8 week intervention, patients were examined by blinded assessors. Self reported health status included the HAQ, Short Form-36 (SF-36), physical scales from the Arthritis Impact Measurement Scales (AIMS-2), pain, global assessment of disease activity, fatigue (100 mm visual analogue scale), and self efficacy.

At the final examination patients stated preferences for tai chi compared with previous conventional exercise, considering the usefulness of the method and the enjoyment experienced ( $100 \mathrm{~mm}$ Likert scales $(50=$ equality, 100 favours tai chi)). Physical performance tests measured muscle function in the shoulders and arms (high scores $=$ good function), ${ }^{7}$ the index of muscle function in the lower extremities $($ low scores $=$ good function $),{ }^{8}$ grip strength 
Table 1 Health status, performance tests, and clinical measures before, during, and after intervention with tai chi exercise

\begin{tabular}{|c|c|c|c|}
\hline & Baseline & 4 Weeks & 8 Weeks \\
\hline $\mathrm{HAQ}(0-3)$ & $1.09(0.83$ to 1.35$)$ & $0.99(0.71$ to 1.27$)$ & $1.07(0.73$ to 1.37$)$ \\
\hline Pain (0-100) & $32(19$ to 43$)$ & $32(18$ to 46$)$ & $34(24$ to 45$)$ \\
\hline Patient global (0-100) & $30(21$ to 40$)$ & 35 (21 to 48$)$ & $32(23$ to 41$)$ \\
\hline Fatigue $(0-100)$ & 42 (27 to 57$)$ & 39 (24 to 54$)$ & 48 (35 to 62$)$ \\
\hline \multicolumn{4}{|l|}{ SF-36 (0-100) } \\
\hline Physical functioning & 51 (39 to 62) & 54 (41 to 67$)$ & 49 (35 to 62 ) \\
\hline Role physical & 21 (4 to 38$)$ & 31 (10 to 53$)$ & 25 (4 to 46$)$ \\
\hline Bodily pain & 43 (35 to 52$)$ & 45 (37 to 52$)$ & $43(36$ to 51$)$ \\
\hline General health & $53(43$ to 51$)$ & 47 (36 to 58$)$ & 46 (37 to 55$)$ \\
\hline Vitality & $40(30$ to 50$)$ & $47(38$ to 56$)$ & $49(42$ to 55$)$ \\
\hline Social functioning & 73 (63 to 84$)$ & 73 (60 to 87$)$ & $74(62$ to 87$)$ \\
\hline Role emotional & 43 (21 to 66$)$ & 49 (21 to 77$)$ & 50 (25 to 75$)$ \\
\hline Mental health & 72 (63 to 82 ) & 79 (71 to 88$)$ & 76 (69 to 84$)$ \\
\hline \multicolumn{4}{|l|}{ AlMS2 (0-10) } \\
\hline Mobility & $1.7(1.0$ to 2.4$)$ & $1.7(1.0$ to 2.4$)$ & $1.7(1.1$ to 2.3$)$ \\
\hline Walking and bending & $3.9(2.9$ to 4.8$)$ & $3.5(2.6$ to 4.5$)$ & $3.6(3.0$ to 4.5$)$ \\
\hline Hand and finger function & 3.3 (2.7 to 4.4$)$ & 3.5 (2.8 to 4.3$)$ & 3.1 (2.3 to 4.0 ) \\
\hline Arm function & $1.0(0.4$ to 1.6$)$ & $1.0(0.4$ to 1.6$)$ & $0.9(0.3$ to 1.6$)$ \\
\hline \multicolumn{4}{|l|}{ Self efficacy (10-100) } \\
\hline Pain & 56.8 (49.0 to 64.6 ) & $55.3(48.1$ to 62.6$)$ & 58.3 (52.0 to 64.5 ) \\
\hline Function & 76.4 (70.8 to 81.9$)$ & 81.2 (75.2 to 87.3$)$ & 77.7 (69.5 to 86.0$)$ \\
\hline Symptoms & 69.9 (63.6 to 76.2$)$ & 64.1 (55.6 to 72.6$)$ & 68.3 (60.7 to 76.0$)$ \\
\hline Function of arm/shoulder (0-60) & $54(50$ to 58$)$ & $53(47$ to 56$)$ & $52(48$ to 55$)$ \\
\hline Index of muscle function total $(0-40)$ & $5.0(2.3$ to 7.7$)$ & $4.7(1.5$ to 8.0$)$ & $4.6(1.6$ to 7.6$)$ \\
\hline General mobility (0-6) & $0.6(0.1$ to 1.1$)$ & $0.5(0.0$ to 1.0$)$ & $0.6(0.2$ to 1.0$)$ \\
\hline Muscle strength $(0-14)$ & $1.4(0.4$ to 2.4$)$ & $1.5(0.1$ to 3.0$)$ & $1.3(-0.1$ to 2.8$)$ \\
\hline Balance/coordination (0-10) & $1.7(0.8$ to 2.7$)$ & $2.0(0.8$ to 3.2$)$ & $1.9(0.8$ to 3.0$)$ \\
\hline Endurance (0-10) & $1.3(0.4$ to 2.2$)$ & $0.7(0.1$ to 1.3$)$ & $0.8(0.0$ to 1.6$)$ \\
\hline Grip strength (max dominant hand) & 107 (71 to 144$)$ & $99(61$ to 137$)$ & 114 (76 to 142$)$ \\
\hline 6 Minute walking distance $(\mathrm{m})$ & 534 (489 to 580 ) & 534 (480 to 587$)$ & 539 (492 to 586 ) \\
\hline Pulse after 6 minutes walking $(/ \mathrm{min})$ & 118 (108 to 129$)$ & $119(111$ to 127$)$ & $119(110$ to 128$)$ \\
\hline Borg scale (0-15) & $12.5(11.5$ to 13.4$)$ & $12.3(10.7$ to 13.8$)$ & $13.1(11.8$ to 13.4$)$ \\
\hline Swollen joints $(0-28)$ & $5.3(3.1$ to 7.4$)$ & $5.9(3.0$ to 8.9$)$ & $5.5(2.8$ to 8.2$)$ \\
\hline Tender joints (0-28) & $10.3(6.2$ to 14.5$)$ & $11.7(7.6$ to 15.9$)$ & $11.6(6.5$ to 16.7$)$ \\
\hline Physician global (0-100) & $23(14$ to 31$)$ & $25(14$ to 37$)$ & $26(19$ to 33$)$ \\
\hline CRP (mg/l) & $5(3$ to 7$)$ & $6(3$ to 9$)$ & $4(2$ to 7$)$ \\
\hline $\operatorname{ESR}(\mathrm{mm} / 1 \mathrm{st} h)$ & $16(5$ to 26$)$ & $16(7$ to 26$)$ & $14(4$ to 24$)$ \\
\hline Disease activity score (DAS28) & 4.32 (3.73 to 4.90$)$ & 4.58 (3.85 to 5.31$)$ & 4.28 (3.59 to 4.96 ) \\
\hline
\end{tabular}

(Grippit handgrip force in the dominant hand), and the 6 minute walking test. The disease activity score (DAS28) was calculated from 28 joint counts, erythrocyte sedimentation rate, and patient global assessment.

The teaching programme included a standardised 8 week instruction programme with tai chi exercise (adapted Sun style for patients with arthritis ${ }^{9}$ ) twice weekly for 45 minutes, given by two instructors certified in teaching Sun style. The programme aimed at improving muscle strength, joint flexibility, and balance.

\section{RESULTS AND DISCUSSION}

All 15 patients completed the 8 week intervention and all assessments. No injuries were received during the exercise sessions. Self reported health status measures did not improve or deteriorate during the study (table 1). Similarly, no changes were seen in the performance measures (muscle strength, flexibility, balance, and cardiovascular fitness), joint counts, laboratory measures for inflammation, and disease activity. Patients, with the exception of two, clearly preferred tai chi to their previous physiotherapeutic intervention, finding it more useful and more enjoyable.

Tai chi instruction and exercise over 8 weeks in this study was safe und feasible, but it did not improve measures of physical function, self reported health status, or disease activity. However, most study subjects clearly favoured tai chi compared with other physical exercise. A major study limitation was the small number of subjects, and another, the short follow up. Usually an intervention period of 1012 weeks with tai chi has been advocated, ${ }^{5} 610$ so that patients can adapt to the concept of tai chi and gradually increase exercise intensity. Furthermore, several of the physical performance measures showed a ceiling effect, with good scores at baseline, and measures with higher responsiveness should be selected. Tai chi has in other studies improved arthritic symptoms in osteoarthritis, ${ }^{5}$ but not in RA. $^{10}$

These findings from a pilot study do not justify a controlled trial, but support further explorative investigations of tai chi in RA.

\section{Authors' affiliations}

T Uhlig, C Larsson, A-G Hiorth, National Resource Centre for Rehabilitation in Rheumatology, Department of Rheumatology, Diakonhjemmet Hospital, N-0319 Oslo, Norway

S Ødegård, T K Kvien, Department of Rheumatology, Diakonhjemmet Hospital, N-0319 Oslo, Norway

Correspondence to: Dr T Uhlig, till.uhlig@nrrk.no

Accepted 6 July 2004

\section{REFERENCES}

1 Gillespie LD, Gillespie WJ, Robertson MC, Lamb SE, Cumming RG, Rowe BH. Interventions for preventing falls in elderly people. Cochrane Database Syst Rev 2001:CD000340.

2 Lan C, Lai JS, Wong MK, Yu ML. Cardiorespiratory function, flexibility, and body composition among geriatric Tai Chi Chuan practitioners. Arch Phys Med Rehabil 1996;77:612-16.

3 Li F, Harmer P, McAuley E, Duncan TE, Duncan SC, Chaumeton N, et al. An evaluation of the effects of Tai Chi exercise on physical function among older persons: a randomized contolled trial. Ann Behav Med 2001;23:139-46. 
4 Wu G, Zhao F, Zhou X, Wei L. Improvement of isokinetic knee extensor strength and reduction of postural sway in the elderly from long-term Tai Chi exercise. Arch Phys Med Rehabil 2002;83:1364-9.

5 Hartman CA, Manos TM, Winter C, Hartman DM, Li B, Smith JC. Effects of T'ai Chi training on function and quality of life indicators in older adults with osteoarthritis. J Am Geriatr Soc 2000;48:1553-5.

6 Song R, Lee EO, Lam P, Bae SC. Effects of tai chi exercise on pain, balance, muscle strength, and perceived difficulties in physical functioning in older women with osteoarthritis: a randomized clinical trial. J Rheumatol 2003;30:2039-44.
7 Boström C, Harms-Ringdahl K, Nordemar R. Clinical reliability of shoulder function assessment in patients with rheumatoid arthritis. Scand J Rheumatol $1991 ; 20: 36-48$

8 Ekdahl C, Andersson SI, Svensson B. Muscle function of the lower extremities in rheumatoid arthritis and osteoarthrosis. A descriptive study of patients in a primary health care district. J Clin Epidemiol 1989:42:947-54.

9 Lam P. A specially designed Tai Chi program for arthritis [abstract]. Arthritis Rheum 1999;42(suppl):S329.

10 Kirsteins AE, Dietz F, Hwang SM. Evaluating the safety and potential use of a weight-bearing exercise, Tai-Chi Chuan, for rheumatoid arthritis patients. Am J Phys Med Rehabil 1991;70:136-41.

\section{Chronic myeloid leukaemia and tuberculosis in a patient with rheumatoid arthritis treated with infliximab}

\section{F Broussais, M Kawashima, H Marotte, P Miossec}

C ases of lymphoma and tuberculosis (TB) have been described in patients receiving tumour necrosis factor $\alpha$ $(\mathrm{TNF} \alpha)$ inhibitors. ${ }^{12}$ We report a case of chronic myeloid leukaemia (CML) and TB, where molecular markers could be followed in a rheumatoid patient treated with infliximab.

\section{CASE REPORT}

A 56 year old white woman, with a 2 year history of refractory and destructive rheumatoid arthritis (RA), had been treated with methotrexate (MTX, $10 \mathrm{mg} /$ week). As this was not effective, MTX was increased to $15 \mathrm{mg} /$ week, and she received a total amount of about $1250 \mathrm{mg}$. Because of persistent active disease and high erythrocyte sedimentation rate $(44 \mathrm{~mm} / \mathrm{lst} \mathrm{h})$ with high platelet count at $0.6 \times 10^{12} / \mathrm{l}$, infliximab was combined with MTX ( $15 \mathrm{mg} /$ week) in August 2001 at $3 \mathrm{mg} / \mathrm{kg}$ every 8 weeks. ${ }^{3}$ It should be noted that at that time TB prophylaxis before starting anti-TNF $\alpha$ treatment was not yet organised as it is today.

Although the disease improved, thrombocytosis, first considered as possibly related to inflammation, increased up to $1.1 \times 10^{12} / 1$ in January 2002 . Bone marrow aspiration demonstrated typical features of CML with the $(9 ; 22)$ (q34; q11) translocation. Infliximab was stopped. After a month of treatment with hydroxycarbamide $(500 \mathrm{mg}$, three times a day), the platelet count decreased to $0.5 \times 10^{12} / 1$. Hydroxycarbamide was stopped and interferon alfa (IFN $\alpha$ ) was started in April 2002 at 8 million units a day, until August 2002. Such treatment was not well tolerated, and a weight loss of more than $10 \%$ of body weight, mild fever, and persistent bronchitis ensued, which were first thought possibly to be related to the IFN $\alpha$.

In June 2002, because of cachexia and lung symptoms a chest $x$ ray examination was carried out, which showed extensive caverns of typical TB. Some of these lesions were already evident on a film taken in 1993, strongly suggesting that the TB had been reactivated in a patient who should have received antibiotics before starting infliximab. Mycobacterium tuberculosis was grown from three consecutive sputum analyses. A four drug regimen was initiated for 2 months, followed by isoniazide and rifampicin for 4 months. Because of persistent anorexia and depression, IFN $\alpha$ treatment was replaced by STI 571 at $600 \mathrm{mg} /$ day. At the time of writing, the patient remains in haematological remission. Joint manifestations are limited to arthralgia, treated with non-steroidal anti-inflammatory drugs.

$B c r$-abl transcript was detected by reverse transcriptasepolymerase chain reaction at the time of CML diagnosis at a level of $0.5 \times 10^{-2}$. This level decreased with myelosuppressive agents to $0.5 \times 10^{-4}$. In addition, using RNA collected from this patient before infliximab treatment, the transcript could be detected at $0.5 \times 10^{-3}$ before the first infusion, indicating that CML was present before infliximab treatment. Its rate of expression appeared to increase during infliximab treatment, suggesting that such treatment has an effect on clonal expansion, although the mutation was already detected before treatment was started (fig 1).

To our knowledge, this is the first description of a diagnosis of CML during infliximab treatment. ${ }^{4}$ Available data are insufficient to draw conclusions as to whether CML developed as part of the natural history of the underlying medical conditions, or whether it occurred as a complication related to a cell mediated immune defect. ${ }^{5}$

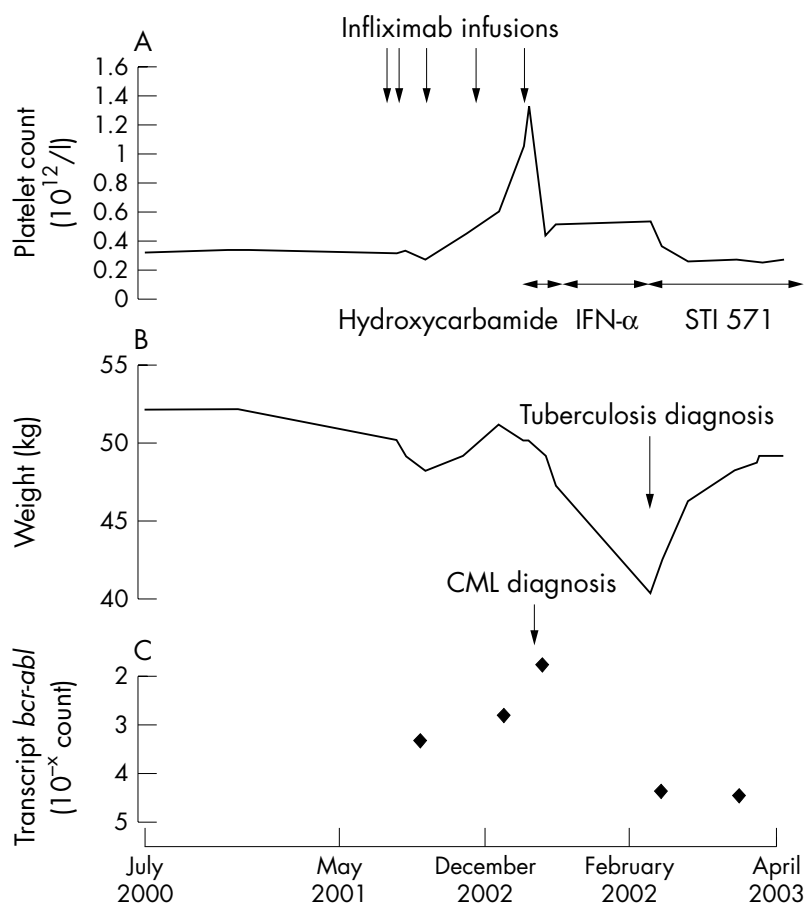

Figure 1 Clinical course and main biological variables for TB and CML diagnosis. (A) The course of the platelet count during infliximab infusions and treatment against CML. (B) Body weight is shown. (C) Kinetics of the bcr-abl transcript expression. 


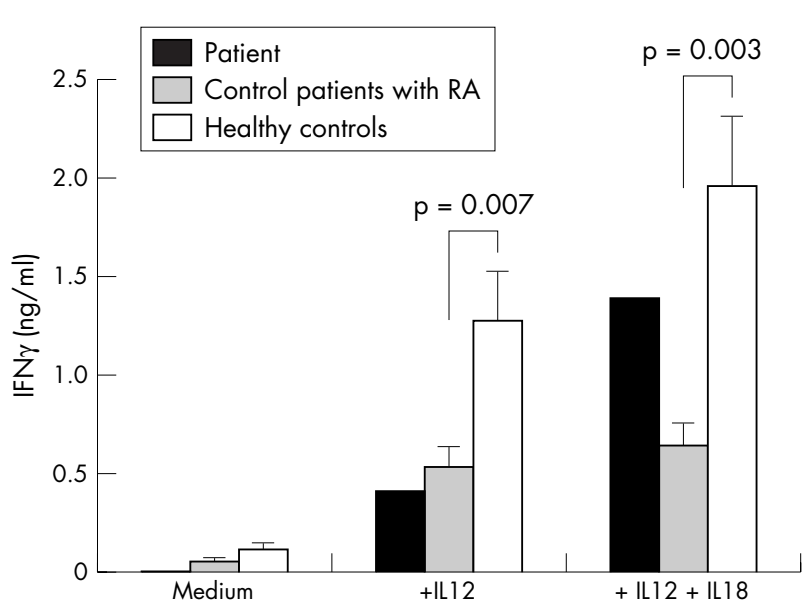

Figure 2 Th1 immune defect in this and other patients with RA. PBMC from the patient, control patients with RA $(n=15)$, and healthy controls $(\mathrm{n}=14)$ were stimulated with or without $1 \mathrm{ng} / \mathrm{ml}$ of IL1 2 or a combination of IL12 $(1 \mathrm{ng} / \mathrm{ml})$ and IL1 $8(5 \mathrm{ng} / \mathrm{ml})$. IFN $\gamma$ concentrations in the culture supernatants were measured by an enzyme linked immunosorbent assay (ELISA). $p$ Values compare controls and patients with RA.

The simultaneous occurrence of TB suggests that this patient had a cell mediated immune defect because she developed TB quickly after the initiation of infliximab treatment as for the other anti-TNF related cases. ${ }^{2}$ To explore the systemic immune function, a bioassay based on the induction of IFN $\gamma$ production by interleukin (IL) 12 and/or IL18 used peripheral blood mononuclear cells (PBMC) from this patient, 15 patients with RA, and 14 healthy controls. ${ }^{6}$ PBMC from this patient were collected during treatment for TB and CML (September 2002) and were stimulated or not with ILl2 $(1 \mathrm{ng} / \mathrm{ml})$ and IL18 $(5 \mathrm{ng} / \mathrm{ml})$ for 7 days. In comparison with the controls, the patient showed a reduced production of IFN $\gamma$ in response to IL12 and IL18, which are key factors for a Thl response (fig 2). This in vitro finding suggests the presence of a systemic immune defect as reflected by an acute $\mathrm{TB}$ reactivation. In this particular patient the additional contribution of CML and its treatment has to be considered.

\section{DISCUSSION}

Screening for $\mathrm{TB}$, as would be done today in this particular case, should have prevented the severe reactivation seen here. Although such a procedure has been particularly effective, the long term immunosuppressive effects of infliximab are unknown. Infliximab treatment is still too recent for a full assessment of its long term safety to be made, and postmarketing follow up is required to define its long term effect on malignancies, particularly on lymphomas and leukaemias.

\section{Authors' affiliations \\ F Broussais, M Kawashima, H Marotte, P Miossec, Departments of Immunology and Rheumatology and HCL-bioMérieux Research Unit on} Rheumatoid Arthritis, Lyon, France

Correspondence to: Professor P Miossec, Clinical Immunology Unit, Departments of Immunology and Rheumatology, Hôpital Edouard Hérriot, 69437 Lyon Cedex 03, France; miossec@univ-lyon 1.fr

Accepted 20 June 2004

\section{REFERENCES}

1 Brown SL, Greene MH, Gershon SK, Edwards ET, Braun MM. Tumor necrosis factor antagonist therapy and lymphoma development: twenty-six cases reported to the Food and Drug Administration. Arthritis Rheum 2002;46:3151-8.

2 Keane J, Gershon S, Wise RP, Mirabile-Levens E, Kasznica J, Schwieterman WD, et al. Tuberculosis associated with infliximab, a tumor necrosis factor alpha-neutralizing agent. N Engl J Med $2001 ; 345: 1098-104$.

3 Maini R, St Clair EW, Breedveld F, Furst D, Kalden J, Weisman M, et al. Infliximab (chimeric anti-tumour necrosis factor alpha monoclonal antibody) versus placebo in rheumatoid arthritis patients receiving concomitant methotrexate: a randomised phase III trial. ATTRACT Study Group. Lancet 1999;354:1932-9.

4 Bakland G, Nossent H. Acute myelogenous leukaemia following etanercept therapy. Rheumatology (Oxford) 2003;42:900-1.

5 Ekstrom K, Hjalgrim H, Brandt L, Baecklund E, Klareskog L, Ekbom A, et al. Risk of malignant lymphomas in patients with rheumatoid arthritis and in their first-degree relatives. Arthritis Rheum 2003;48:963-70.

6 Kawashima M, Miossec P. Decreased response to IL-12 and IL-18 of peripheral blood cells in rheumatoid arthritis. Arthritis Res Ther 2004;6:R39-45.

\section{Muscarinic acetylcholine receptor autoantibodies in patients with Sjögren's syndrome}

\section{Y Naito, I Matsumoto, E Wakamatsu, D Goto, T Sugiyama, R Matsumura, S Ito, A Tsutsumi, T Sumida}

S jögren's syndrome (SS) is an autoimmune disease characterised by lymphocytic infiltration into the lachrymal and salivary glands, leading to dry eyes and mouth. Infiltration is also found in the kidneys, lungs, thyroid, and liver. Immunohistochemical studies have shown that most infiltrating lymphocytes around the labial salivary and lachrymal glands, and kidneys are CD4 positive $\alpha \beta \mathrm{T}$ cells. Previous studies with polymerase chain reaction provide evidence about the $\mathrm{T}$ cell receptor $\mathrm{V} \beta$ and $\mathrm{V} \alpha$ genes on these $\mathrm{T}$ cells, and sequence analysis of the CDR3 region indicates some conserved amino acid motifs, supporting the notion that infiltrating $\mathrm{T}$ cells recognise relatively few epitopes on autoantigens. ${ }^{1}$
Candidate autoantigens recognised by $\mathrm{T}$ cells infiltrating the labial salivary glands of patients with SS have been analysed, and Ro/SSA $52 \mathrm{kDa}, \alpha$-amylase, heat shock protein, and $\mathrm{T}$ cell receptor $\mathrm{BV}^{2}$ have been identified. However, there is no direct evidence that these reactive $\mathrm{T}$ cells really attack and destroy the salivary glands. In contrast, the presence of autoantibodies (Abs) against M3 muscarinic acetylcholine receptor (M3R) has been reported, and it is suggested that an immune reaction to M3R plays a crucial part in the generation of SS. ${ }^{3-5}$ Robinson, et al demonstrated that human anti-M3R Abs reduce the secretory function in NOD.Ig $\mu$ null mice. ${ }^{3}$ Moreover, Bacman et al clearly showed that human Abs against the second extracellular loop of M3R could 


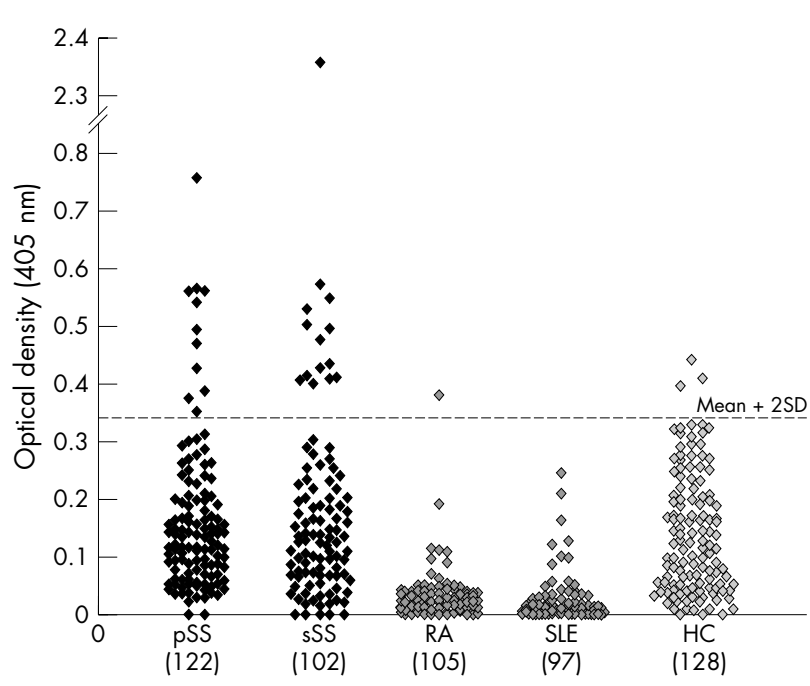

Figure 1 Optical density. pSS, primary Siögren's syndrome; sSS, secondary Siögren's syndrome, RA, rheumatoid arthritis, SLE, systemic lupus erythematosus, $\mathrm{HC}$, healthy controls. Numbers in parentheses represent the number of patients in each group.

activate nitric oxide synthase coupled to the lachrymal gland M3R, suggesting that anti-M3R Abs are a new marker of dry eye SS. ${ }^{4}$ The M3Rs are expressed on salivary and lachrymal glands, and thus they should be key receptors involved in the production of saliva and tears after stimulation of acetylcholine. Thence, autoantibodies against M3R could interfere with the production of saliva and tears. To test this hypothesis we analysed the prevalence of anti-M3R Abs in patients with SS.

Approval for this study was obtained from the local ethics committee and written informed consent was obtained from all patients and volunteers who participated in this study.

\section{METHODS}

Serum samples were collected from 122 Japanese patients with primary SS and 102 Japanese patients with secondary SS followed up at the Department of Internal Medicine, University of Tsukuba Hospital, Japanese Red Cross Mito Hospital, and Shimosizu National Hospital. All patients with SS satisfied the Japanese Ministry of Health criteria for the classification of SS. We also recruited 105 patients with rheumatoid arthritis, 97 with systemic lupus erythematosus, and 128 healthy subjects from our University.

A 25mer peptide (KRTVPPGECFIQFLSEPTITFGTAI) corresponding to the sequence of the second extracellular loop domain of the human M3R was synthesised (Kurabo Industries, Osaka, Japan). As a negative peptide, a 25mer peptide (SGSGSGSGSGSGSGSGSGSGSGSGS) was also synthesised (Kurabo Industries). Peptide solution (100 $\mu \mathrm{l} /$ well at $10 \mu \mathrm{g} / \mathrm{ml}$ ) in $0.1 \mathrm{M} \mathrm{Na}_{2} \mathrm{CO}_{3}$ buffer, $\mathrm{pH}$ 9.6, was adsorbed to a Nunc-Immuno plate (Nalge Nunc International, Rochester, NY) at $4{ }^{\circ} \mathrm{C}$ overnight, and blocked with 5\% bovine serum albumin (Wako Pure Chemical Industries, Osaka) in phosphate buffered saline (PBS) for 1 hour at $37^{\circ} \mathrm{C}$. Serum at 1:50 dilution in blocking buffer was incubated for 2 hours at $37^{\circ} \mathrm{C}$. The plates were then washed three times with $0.05 \%$ Tween 20 in PBS, and $1 \mu \mathrm{l}$ of alkaline phosphatase conjugated goat antihuman IgG (Fc; American Qualex, San Clemente, CA) diluted 1:1000 in PBS was added for 1 hour at room temperature. After extensive washing, $100 \mu \mathrm{l}$ of $p$-nitrophenyl phosphate (Sigma, St Louis, MO) solution (final concentration $1 \mathrm{mg} / \mathrm{ml}$ ) was added as alkaline phosphatase substrate. Plates were incubated for 1 hour at room temperature and the optical density at $405 \mathrm{~nm}$ was measured by plate spectrophotometry (Bio-Rad Laboratories, Hercules, CA; fig 1). Determinations were performed in triplicate and standardised between experiments.

\section{RESULTS AND DISCUSSION}

The 25mer synthetic amino acid encoding the second extracellular domain of M3R was used as the antigen, because this portion has an important role in intracellular signalling. ${ }^{6}$ The binding activity of Abs to the second extracellular domain of M3R is dependent on the concentration of Abs using serial-diluted quantitative assay (data not shown). Figure 1 shows that Abs against M3R were more commonly detected in the serum of patients with primary $(11 / 122(9 \%), p<0.05)$ and secondary SS $(14 / 102(14 \%)$, $\mathrm{p}<0.05$ ) than in those with other autoimmune diseases such as rheumatoid arthritis (1/105 (1\%)) and systemic lupus erythematosus $(0 / 97(0 \%))$, or healthy subjects $(3 / 128(2 \%))$. These results clearly showed that autoantibodies against M3R are specifically present in SS, suggesting that anti-M3R Abs could be used as a diagnostic marker in a subgroup of patients with SS (9-14\%). The proportions of patients positive for anti-M3R Ab and anti-SSA Ab, anti-SSB Ab, rheumatoid factor, and antinuclear factor were $68 \%, 29 \%$, $57 \%$, and $83 \%$. In contrast, the proportions of patients negative for anti-M3R Ab with these autoantibodies were $65 \%, 6 \%, 59 \%$, and $76 \%$, respectively. Thus, anti-SSB Ab is strongly associated with anti-M3R Ab $(\mathrm{p}<0.05)$, although the homology between SSB and the M3R molecule is very low and the detailed mechanism remain unclear. The clinical feature is not significantly different between in patients with SS positive for anti-M3R Ab and negative patients.

In conclusion, we detected autoantibodies against M3R in a subgroup of patients with SS, suggesting that anti-M3R Ab could be used as a new diagnostic marker for SS. Further experiments on the functional analysis of anti-M3R Abs in SS using M3R transfectant cell lines should shed light on the relationship between the presence of anti-M3R autoantibodies and the pathogenesis of SS.

\section{Authors' affiliations \\ Y Naito, I Matsumoto, E Wakamatsu, D Goto, S Ito, A Tsutsumi, \\ T Sumida, University of Tsukuba, Ibaraki, Japan \\ T Sugiyama, Shimoshizu National Hospital, Chiba, Japan \\ R Matsumura, Toho University Sakura Hospital, Chiba, Japan}

Correspondence to: Professor T Sumida, Department of Internal Medicine, University of Tsukuba, 1-1-1 Tennodai, Tsukuba City, Ibaraki 305-8575, Japan; tsumida@md.tsukuba.ac.jp

Accepted 17 July 2004

\section{REFERENCES}

1 Sumida T, Matsumoto I, Maeda T, Nishioka K. T-cell receptor in Sjögren' s syndrome. Br J Rheumatol 1997;36:622-9.

2 Sumida T. T cells and autoantigens in Sjögren's syndrome. Mod Rheumatol 2000;10:193-8.

3 Robinson CP, Brayer J, Yamachika S, Esch TR, Peck AB, Stewart CA, et al. Transfer of human serum IgG to nonobese diabetic Igunull mice reveals a role for autoantibodies in the loss of secretory function of exocrine tissues in Sjögren's syndrome. Proc Natl Acad Sci USA 1998;95:7538-43.

4 Bacman S, Berra A, Sterin-Borda L, Borda E. Muscarinic acetylcholine receptor antibodies as a new marker of dry eye Sjögren's syndrome. Invest Ophthalmol Vis Sc 2001;42:321-7.

5 Nguyen K, Brayer J, Cha S, Diggs S, Yasunori U, Hilal G, Peck AB, Humphreys-Beher MG. Evidence for anti-muscarinic acetylcholine receptor antibody-mediated secretory dysfunction in NOD mice. Arthritis Rheum 2000:43:2297-306

6 Kostenis E, Zeng FY, Wess J. Structure-function analysis of muscarinic receptors and their associated G proteins. Life Sci 1999;64:355-62. 